\title{
Nematode larvae infecting Priacanthus arenatus Cuvier, 1829 (Pisces: Teleostei) in Brazil
}

\author{
BIANCA P. KURAIEM ${ }^{1}$, MARCELO KNOFF ${ }^{2}$, NILZA N. FELIZARDO ${ }^{1}$, \\ DELIR C. GOMES ${ }^{2}$ and SÉRGIO C. SÃO CLEMENTE ${ }^{1}$
}

\author{
${ }^{1}$ Laboratório de Inspeção e Tecnologia do Pescado, Faculdade de Medicina Veterinária, Universidade \\ Federal Fluminense/UFF, Rua Vital Brasil, 64, Vital Brazil, 24320-340 Niterói, RJ, Brasil \\ ${ }^{2}$ Laboratório de Helmintos Parasitos de Vertebrados, Instituto Oswaldo Cruz/FIOCRUZ, \\ Av. Brasil, 4365, Manguinhos, 21045-900 Rio de Janeiro, RJ, Brasil
}

Manuscript received on February 23, 2015; accepted for publication on May 8, 2015

\begin{abstract}
From July to December, 2013, thirty Priacanthus arenatus specimens commercialized in the cities of Niterói and Rio de Janeiro, State of Rio de Janeiro, were acquired. The fish were necropsied and filleted to investigate the presence of nematode larvae. Twenty fish (66.7\%) out of the total were parasitized by nematode larvae. A total of 2024 larvae were collected; among them, 30 third-instar larvae of Anisakis sp. showed prevalence $(\mathrm{P})=20 \%$, mean abundance $(\mathrm{MA})=1$, and the mean intensity $(\mathrm{MI})=5$, and infection sites (IS) = caecum, stomach, liver, and mesentery; and 1,994 third-instar larvae (1,757 encysted and 237 free) of Hysterothylacium deardorffoverstreetorum with $\mathrm{P}=66.7 \%$, MA $=66.5$, and $\mathrm{MI}=99.7$, and IS = spleen, caecum, stomach, liver, mesentery, and abdominal muscle. This is the first study to report $H$. deardorffoverstreetorum and Anisakis sp. larvae parasitizing P. arenatus.
\end{abstract}

Key words: Anisakidae, Raphidascarididae, Priacanthus arenatus, Brazil.

\section{INTRODUCTION}

Priacanthus arenatus Cuvier, 1829, Atlantic bigeye, occurs in the waters of the western Atlantic. It is a species of nocturnal habits, that lives on the coast in depths of about 130 meters that feeds on small fish, crustaceans, and polychaete (Figueiredo and Menezes 1980).

The nematodes of Anisakidae and Raphidascarididae families parasitize marine mammals and have teleost fish, crustaceans, and small cephalopod molluscs as intermediate hosts (Adams et al. 1997, Anderson 2000). Humans are an accidental host,

Correspondence to: Marcelo Knoff

E-mail: knoffm@ioc.fiocruz.br acquiring the larvae by eating raw or undercooked, smoked, or insufficiently salted fish (Amato and Barros 1984).

Some species of parasites found in fishery products are capable of causing diseases if ingested, such as anisakidosis caused by nematodes larvae of Anisakidae (Adams et al. 1997, Klimpel and Palm 2011). Adult of Hysterothylacium Ward \& Magath, 1917, belonging to the Raphidascarididae, has also identified as an accidental parasite of humans (Yagi et al. 1996). In 2010, a unique anisakidosis case was reported in Brazil, in a 73-years-old man in the of Barra do Garças city, State of Mato Grosso, with the larvae located in the duodenum mucosa (Cruz et al. 2010). 
These parasites also have importance in seafood sanitary inspection by the repugnant aspect in fish with large infestation by these parasites. According to the Regulation of Industrial and Sanitary Inspection of Animal Products - RIISPOA (Regulamento da Inspeção Industrial e Sanitária de Produtos de Origem Animal) (Brasil 1997), Article 445 , item 4 , the seafood with massive muscle parasite infestation is considered inappropriate for human consumption.

This study aimed to investigate the parasitism of the nematode larvae present in $P$. arenatus commercialized in the cities of Niterói and Rio de Janeiro, State of Rio de Janeiro, Brazil; identify the helminth larvae taxonomy; establish the parasite indices as prevalence (P), mean abundance (MA), mean intensity (MI), and infection sites (IS); and evaluate the importance in detecting the presence of helminths in seafood for public health.

\section{MATERIALS AND METHODS}

From July to December, 2013, thirty P. arenatus specimens were acquired measuring $20-63 \mathrm{~cm}$ total length and weighing 400-3.600 $\mathrm{g}$ from the fish markets in the cities of Niterói and Rio de Janeiro, State of Rio de Janeiro, Brazil. These fish were transported in isothermal boxes to the Laboratory of Inspection and Fish Technology of the Veterinary Medicine School of the Fluminense Federal University, where they were necropsied and filleted. The fish species was identified according to Figueiredo and Menezes (1980). Collected nematodes were fixed in hot ethanol 70 ${ }^{0} \mathrm{GL}$, formaldehyde, and acetic acid (AFA ) $(65$ ${ }^{\circ} \mathrm{C}$ ) and subsequently stored in ethanol $70{ }^{\circ} \mathrm{GL} 5 \%$ glycerinated, clarified with Aman's Lactophenol, according to Knoff and Gomes (2012). The used taxonomic classification for Anisakidade and Raphidascarididae was in accordance with Fagerholm (1991), and the larvae identification was based on Felizardo et al. (2009a) and Knoff et al. (2012). The larvae were observed using Olympus BX-41 brightfield microscope, and the measurements were obtained in millimeters $(\mathrm{mm})$ with the averages shown in parentheses. The parasitic indices on the prevalence, mean intensity and mean abundance, were calculated according to Bush et al. (1997). Representative specimens of Anisakis sp. and Hysterothylacium deardorffoverstreetorum were deposited in the Helminthological Collection of the Oswaldo Cruz Institute (CHIOC).

\section{RESULTS}

Twenty fish (66.7\%) among the 30 collected were parasitized by nematode larvae; in total, 2,024 parasites were collected. Thirty free larvae of Anisakis sp. and 1,994 H. deardorffoverstreetorum larvae [237 larvae were in free form and 1,757 larvae were inside of granulomas (Figure 1 a-e)] were collected from abdominal cavity. Most larvae were alive and showed high motility.

The morphological and morphometric data of third-instar larvae of the Anisakis sp. and $H$. deardorffoverstreetorum nematodes colleted in $P$. arenatus are presented in Table I. The parasitic indices of prevalence, mean abundance and mean intensity of infection, as well as the infection sites and the deposit number at $\mathrm{CHIOC}$, are depicted in Table II.

Anisakidae Railliet \& Henry, 1912

Anisakis Dujardin, 1845

Anisakis sp. (Figure 2 a-c)

The main morphological characteristics observed in 15 third-instar larvae from $P$. arenatus were: cuticle with delicate transversal striations, most evident in the posterior portion; anterior end with a dorsal lip and two ventrolateral lips poorly developed; six cephalic papillae, a couple in the dorsal lip and a pair in each ventrolateral lip; larval tooth below the mouth opening, between the ventrolateral lips; excretory pore located below the larval tooth; ventricle longer than wide; ventricular appendix and intestinal caecum absent; esophagus approximately twice the ventricle size; two rounded rectal glands; conical tail and mucron present. 

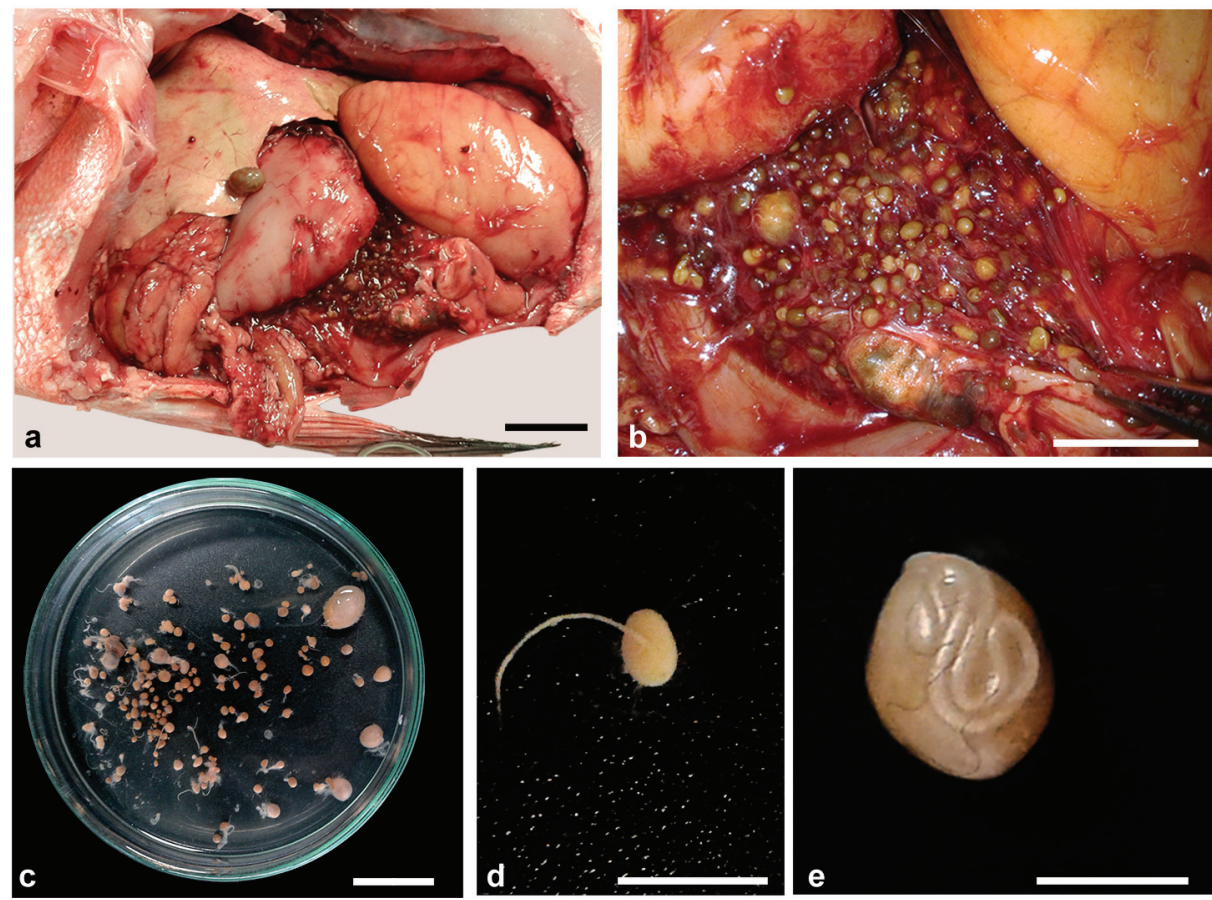

Figure 1 - Granulomas containing third-instar larvae of Hysterothylacium deardorffoverstreetorum on abdominal cavity of Priacanthus arenatus. a. Open abdominal cavity presenting infection with granulomas. b. Detail of the infection. c. Petri dish with newly collected granulomas. d. Larva getting off of the granuloma. e. Encysted larva. The scale bars in $\mathbf{a}$ and $\mathbf{c}=2 \mathrm{~cm}, \mathbf{b}=1 \mathrm{~cm}$, $\mathbf{d}=0.5 \mathrm{~cm}$ and $\mathbf{e}=0.2 \mathrm{~cm}$. See the colors in the online version.

TABLE I

Morphological and morphometric data of third-instar larvae of the Anisakis sp. and Hysterothylacium deardorffoverstreetorum nematodes collected from Priacanthus arenatus (Cuvier, 1829) commercialized in the State of Rio de Janeiro, Brazil.

\begin{tabular}{ccc}
\hline & Anisakis sp. $(\mathrm{n}=15)$ & $\begin{array}{c}\text { Hysterothylacium } \\
\text { deardorffoverstreetorum }(\mathrm{n}=15)\end{array}$ \\
\hline Body (L) & $20.86-28.68(23.04)$ & $6.08-18.38(12.12)$ \\
Body (W) & $0.42-0.56(0.48)$ & $0.18-0.46(0.36)$ \\
Larval tooth & Present & Absent \\
Excretory pore * & Below the larval tooth & Below the nervous ring \\
Nervous ring ** & $0.28-0.45(0.35)$ & $0.27-0.60(0.48)$ \\
Esophagus (L) & $1.42-2.20(1.80)$ & $0.52-1.20(0.87)$ \\
Ventricle (L) & $0.30-1.00(0.80)$ & $0.06-0.20(0.12)$ \\
Ventricle (W) & $0.20-0.30(0.27)$ & $0.09-0.18(0.13)$ \\
Ventricular appendix (L) & Absent & $0.42-1.00(0.71)$ \\
Intestinal caecum (L) & Absent & $0.10-0.48(0.26)$ \\
Tail (L) & $0.08-0.15(0.11)$ & $0.16-0.30(0.24)$ \\
Mucron (L) & $8-32(21.6) \mu \mathrm{m}$ & $1-4(2.7) \mu \mathrm{m}$ \\
\hline
\end{tabular}

\footnotetext{
* Inconspicuous in some specimens; ** Distance from anterior end; $\mathrm{L}=$ length; $\mathrm{W}=$ width;
} $\mathrm{n}=$ number of measured specimens. 
TABLE II

Parasitic indices of prevalence (P), mean intensity (MI) and mean abundance (MA), infection sites (IS), and number of deposit in the Helminthological Collection of the Oswaldo Cruz Institute (CHIOC) of the Anisakis sp. and Hysterothylacium deardorffoverstreetorum larvae from Priacanthus arenatus (Cuvier, 1829) commercialized in the State of Rio de Janeiro, Brazil.

\begin{tabular}{cccccc}
\hline & $\mathrm{P}(\%)$ & MA & MI & IS & CHIOC \\
\hline Anisakis sp. & 20 & 1 & 5 & C, St, L, AM & 35997 \\
$\begin{array}{c}\text { Hysterothylacium } \\
\text { deardorffoverstreetorum }\end{array}$ & 66.7 & 66.5 & 99.7 & Sp, C, St, L, & $35996 \mathrm{a}$, \\
& & & & M, AM & $35996 \mathrm{~b}$, \\
& & & & 35998 \\
\hline
\end{tabular}

$\overline{\mathrm{Sp}}=$ spleen $; \mathrm{C}=$ caecum; $\mathrm{St}=$ stomach; $\mathrm{L}=$ liver; $\mathrm{M}=$ mesentery; $\mathrm{AM}=$ abdominal muscles.

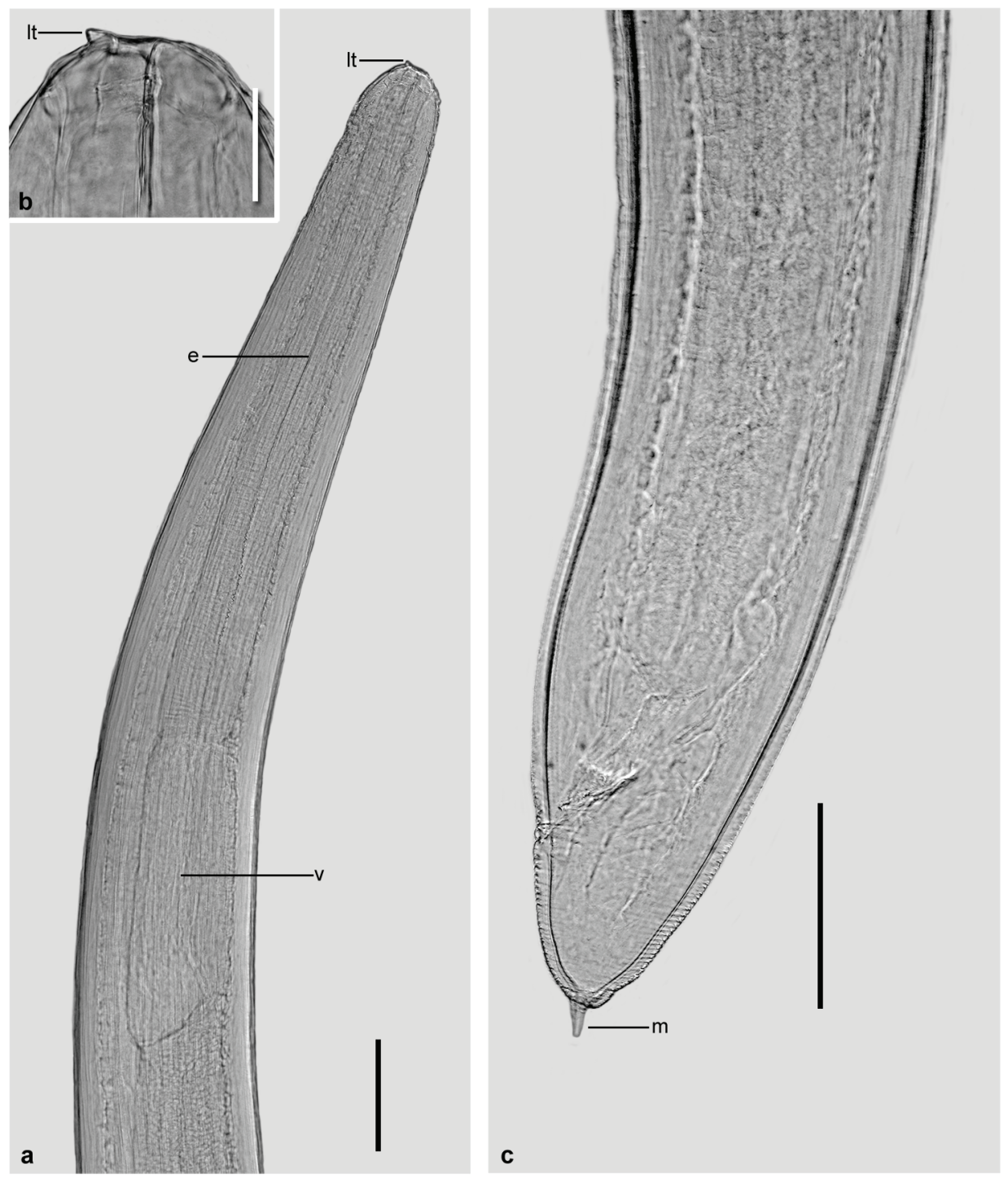

Figure 2 - Third-instar larva of Anisakis sp. a. Anterior end, showing larval tooth (lt), esophagus (e) and ventricle (v). b. Detail of larval tooth (lt) with excretory pore beside. c. Posterior portion, showing the tail with characteristic mucron (m). The scale bars in $\mathbf{a}=200 \mu \mathrm{m}, \mathbf{b}=50 \mu \mathrm{m}$ and $\mathbf{c}=$ $100 \mu \mathrm{m}$. 
Raphidascarididae (Hartwich, 1954) sensu Fagerholm, 1991

Hysterothylacium Ward \& Margath, 1917

Hysterothylacium deardorffoverstreetorum Knoff, Felizardo, Iñiguez, Maldonado Jr, Torres, Pinto \& Gomes, 2012 (Figure 3 a-c)

The main morphological characteristics observed in 15 third-instar larvae from $P$. arenatus were: cuticle with lateral extension along the body, devoid of basal extension; anterior end with a dorsal lip and two ventrolateral lips poorly developed; nine cephalic papillae, two pairs on the dorsal lip near a large papilla and one pair in each ventrolateral lip; larval tooth absent; excretory pore opening below the nervous ring, inconspicuous in some specimens; ventricle slightly spherical; ventricular appendix of similar length to the esophagus; intestinal caecum present; four subspherical rectal glands; conical tail and mucron present.
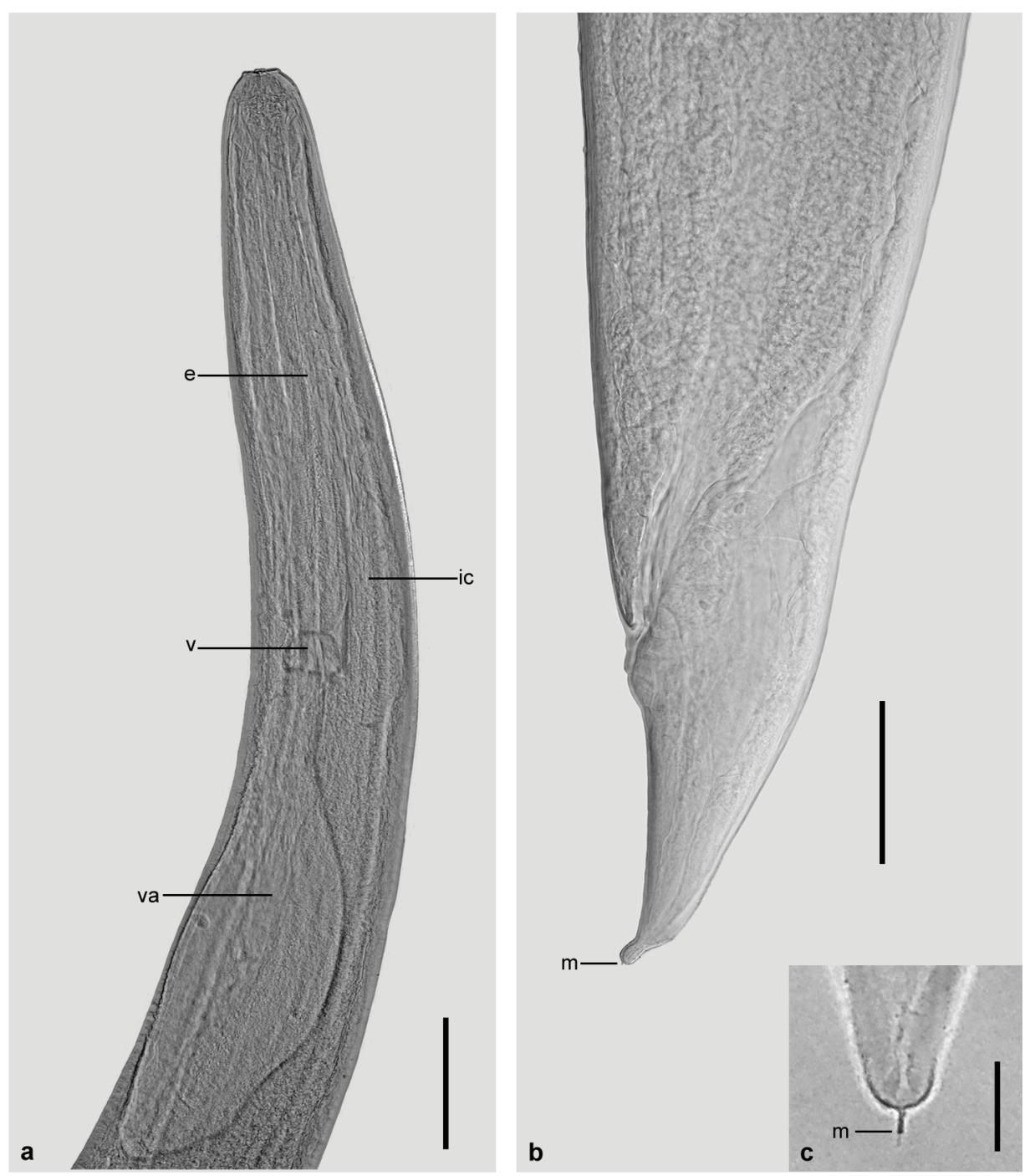

Figure 3 - Third-instar larva of Hysterothylacium deardorffoverstreetorum. a. Anterior end, showing esophagus (e), ventricle (v), ventricular appendix (va) and intestinal caecum (ic). b. Posterior portion, showing the tail with characteristic mucron (m). c. Detail of mucron. The scale bars in $\mathbf{a}=$ $200 \mu \mathrm{m}, \mathbf{b}=500 \mu \mathrm{m}$ and $\mathbf{c}=20 \mu \mathrm{m}$. 


\section{DISCUSSION}

The third-instar larvae of Anisakis sp. found in this study showed morphological similarities with Anisakis simplex larvae collected from Paralichthys isosceles Jordan, 1890 in Brazilian coast by Felizardo et al. (2009a); although slightly larger in size, it showed proportionately similar morphological structures.

The morphology and morphometry of the $H$. deardorffoverstreetorum third-instar larvae collected in $P$. arenatus were similar to those reported by Fontenelle et al. (2013) in Cynoscion guatucupa (Cuvier, 1830) from the State of Rio de Janeiro. These same larvae are similar to those described by Knoff et al. (2012) obtained from P. isosceles on the Brazilian coast, and also morphologically similar to those specimens previously described as Hysterothylacium sp. n. 2 (Petter and Maillard 1988), Hysterothylacium MD (Deardorff and Overstreet 1981), Hysterothylacium KB (Petter and Sey 1997), and Hysterothylacium sp. (Pereira Jr et al. 2004, Ribeiro et al. 2014).

In this study, granuloma formation was observed, due to the presence of $H$. deardorffoverstreetorum larvae, as reported by Felizardo et al. (2009b) in P. isosceles; however, in this study, it was also possible to macroscopically observe the presence of larvae in the surface of these granulomas.

This is the first study to report $P$. arenatus parasitism by $H$. deardorffoverstreetorum and Anisakis sp. larvae.

Anisakis sp. larvae have admittedly zoonotic potential; and $H$. deardorffoverstreetorum larvae can also be considered as having zoonotic potential according to some studies. Although most of these nematodes are present in the abdominal cavity and in the viscera, they are able to migrate into the fish muscle, so there is risk of ingestion by humans. It is highly recommended to educate the population about the dangers of eating raw fish, as well as its acquisition from questionable sources, due to the anisakidosis. Furthermore, there is a pressing need for the intensification of surveillance on seafoodbased food in addition to an effective application of reliable techniques by responsible agencies for inspection and processing, as suggested by Fontenelle et al. (2013) and Ribeiro et al. (2014).

\section{ACKNOWLEDGMENTS}

The authors would like to thank Heloisa Nogueira Diniz and Rodrigo Mexas (Serviço de Produção e Tratamento de Imagens do Instituto Oswaldo Cruz, FIOCRUZ) for processing the figures; and the Conselho Nacional de Desenvolvimento Científico e Tecnológico (CNPq) and Coordenação de Aperfeiçoamento de Pessoal de Nível Superior (CAPES) for partial financial supports.

\section{RESUMO}

Entre julho e dezembro de 2013, foram adquiridos 30 espécimes de Priacanthus arenatus comercializados nos municípios de Niterói e Rio de Janeiro, no estado do Rio de Janeiro. Os peixes foram necropsiados e filetados para investigação da presença de larvas de nematoides. Do total, $20(66,7 \%)$ peixes estavam parasitados com larvas de nematoides. Foram coletadas no total 2024 larvas, das quais, 30 larvas de terceiro estágio de Anisakis sp. com prevalência $(\mathrm{P})=20 \%$, abundância média $(\mathrm{AM})=$ 1 e intensidade média (IM) $=5$, tendo como sítios de infecção (SI) ceco, estômago, fígado e mesentério; e 1994 larvas de terceiro estágio (1757 encistadas e 237 livres) de Hysterothylacium deardorffoverstreetorum com $\mathrm{P}=$ $66,7 \%, \mathrm{AM}=66,5$ e IM $=99,7 \mathrm{e} \mathrm{SI}=$ baço, ceco, estômago, fígado, mesentério e musculatura abdominal. Este é o primeiro registro de larvas de $H$. deardorffoverstreetorum e Anisakis sp. parasitando P. arenatus.

Palavras-chave: Anisakidae, Raphidascarididae, Priacanthus arenatus, Brasil.

\section{REFERENCES}

ADAMS AM, MurRel KD AND CROSS JH. 1997. Parasites of fish and risk to public health. Rev Sci Tech Off Int Epiz 6: $652-660$ 
AMATO JFR AND BARROS GC. 1984. Anisakíase humana no Brasil: Problema inexistente ou mal pesquisado? Rev Bras de Med Vet 6: 12.

ANDERSON RC. 2000. Nematode parasites of vertebrates. Their development and transmission, $2^{\text {nd }}$ ed., London: CABI Publishing, $672 \mathrm{p}$.

BRASIL. 1997. Regulamento de Inspeção Industrial e Sanitária de Produtos de Origem Animal (RIISPOA). Decreto 30.691/52. Brasília, Ministério da Agricultura e do Abastecimento. D.O.U 07/07/1952, seção 1: 10785.

BUSH AO, LAFFERTY KD, LOTZ JM AND SHOSTAK AW. 1997. Parasitology meets ecology on its own terms: Margolis et al. revisited. J Parasitol 83: 575-583.

CRUZ AR, SOUSA SPC, FERRARI CKB, ALLEGRETTI SM AND ARRAIS-SILVA WW. 2010. Endoscopic imaging of the first clinical case of Anisakidosis in Brazil. Sci Parasitol 11: 97-100.

DEARDORFF TL AND OVERSTREET RM. 1981. Larval Hysterothylacium (=Thynnascaris) (Nematoda: Anisakidae) from fishes and invertebrates in the Gulf of Mexico. Proc Helminthol Soc Wash 48: 113-126.

FAGERHOLM HP. 1991. Systematic implications of male caudal morphology in ascaridoid nematode parasites. Syst Parasitol 19: 215-229.

FElizARdo NN, KNOFF M, PINTO RM AND GOMES DC. 2009a. Larval anisakid nematodes of the flounder, Paralichthys isosceles Jordan, 1890 (Pisces: Teleostei) from Brazil. Neotrop Helminthol 3: 57-64.

FElizARdo NN, MENEZES RC, TORTELly R, KNOFF M, PINTO RM AND GOMES DC. 2009b. Larvae of Hysterothylacium sp. (Nematoda: Anisakidae) in the sole fish Paralichthys isosceles Jordan, 1890 (Pisces: Teleostei) from the littoral of the state of Rio de Janeiro, Brazil. Vet Parasitol 166: 175-177.

FigueIREDo JL AND MENEZES N. 1980. Manual de peixes marinhos do sudeste do Brasil III - Teleostei 2. São Paulo: Museu de Zoologia, Universidade de São Paulo, 90 p.

FonTENELlE G, KNOFF M, FELIZARdo NN, LOPES LMS AND SÃo CLEMENTE SC. 2013. Nematodes of zoonotic importance in Cynoscion guatucupa (Pisces) in the state of Rio de Janeiro. Rev Bras Parasitol Vet 22: 281-284.

KLIMPEL S AND PALM HW. 2011. Anisakid nematode (Ascaridoidea) life cycles and distribution: increasing zoonotic potential in the time of climate change? In: Mehlhorn H (Ed), Progress in Parasitology, Parasitology Research Monographs 2, Berlin: Springer Berlin Heidelberg, p. 201-222.

KNOFF M, FELIZARdo NN, InIGUEZ AM, MALDONAdo JR A, TORRES EJL, PINTO RM AND GOMES DC. 2012. Genetic and morphological characterisation of a new species of the genus Hysterothylacium (Nematoda) from Paralichthys isosceles Jordan, 1890 (Pisces: Teleostei) of the Neotropical region, State of Rio de Janeiro, Brazil. Mem Inst Oswaldo Cruz 107: 186-193.

KNOFF M AND GOMES DC. 2012. Metodologia básica para coleta e processamento de helmintos parasitos. In: Molinaro EM, Caputo LFG and Amendoeira MRR (Eds), Conceitos e métodos para a formação de profissionais em laboratórios de saúde. Rio de Janeiro: EPSJV, IOC, p. 251-281.

PEREIRA JR J, ALMEIDA FM, MORAIS NCM AND VIANNA RT. 2004. Hysterothylacium sp. larvae (Nematoda: Anisakidae) in Micropogonias furnieri (Sciaenidae) from Rio Grande do Sul coast, Brazil. Atlântica 26: 55-60.

PETTER AJ AND MAILlard C. 1988. Larves d'ascarides parasites de poissons em Mediterrane occidentale. Bull Mus Hist Natl Paris 10: 347-369.

PETTER JA AND SEY O. 1997. Nematode parasites of marine fishes from Kuwait, with a description of Cucullanus trachinoti n.sp. from Trachinotus blochi. Zoosystema 19: 35-59.

RIBEIRO J, SÃO CLEMENTE SC, LOPES LMS AND KNOFF M. 2014. Nematode larvae of hygienic importance infecting Chaetodipterus faber (Broussonet, 1782) and Trachinotus carolinus (Linnaeus, 1766) (Pisces: Teleostei) in Brazil. Rev Bras Med Vet 36: 121-124.

YAGI K, NAGASAWA K, ISHIKURA H, NAKAGAWA A, SATO N, KIKUCHI K, ISHIKURA K AND ISHIKURA H. 1996. Female worm Hysterothylacium aduncum excreted from human: a case report. J Parasitol 45: 12-23. 
